\title{
Metode Brain Based Learning: Mengembangkan Kemampuan Berfkir Siswa Dalam Pembelajaran Akidah Akhlak
}

\section{Brain Based Learning Method: Developing Students' Thinking Ability in Learning AkidahAkhlak}

\section{Safinatur Robikah}

Program Studi Magister Pendidikan Agama Islam, Universitas Islam Negeri Sunan

Ampel Surabaya

e-mail: safinaturrobikah@gmail.com

\begin{abstract}
Abstrak: Pembelajaran aqidah akhlak membutuhkan sebuah inovasi pembelajaran agar terbentuk iman yang sempurna berdasarkan pemahaman dan pengetahuan siswa. Artikel ini bertujuan mendeskripsikan metode brain based learning dalam pembelajaran aqidah akhlak. Metode penulisan artikel menggunakan pendekatan deskriptif dengan jenis penelitian kajian kepustakaan. Artikel ini menjelaskan bahwa terdapat bermacammacam cara yang dapat dilaksanakan pada pembelajaran aqidah akhlak yang mengaplikasikan metode brain based learning yakni: 1) pembelajaran aqidah akhlak dapat dilaksanakan menggunakan metode hafalan, 2) pembelajaran dengan menunjukkan gambar-gambar, 3) visualisasi berupa vidio dan lain sebagainya, sehingga dengan metode tersebut siswa menjadi lebih aktif serta bersemangat ketika belajar aqidah akhlak. Selain itu pembelajaran dengan menggunakan metode brain based learning terbukti menarik dalam meningkatnya pemahamam pengetahuan siswa, sekaligus juga menjamin peningkatan kemampuan siswa pada umumnya. itu, juga dapat menjamin peningkatan perkembangan kemampuan siswa pada umumnya.
\end{abstract}

Kata Kunci:Pembelajaran, AkidahAkhlak, Brain Based Learning.

Abstract: Aqidah Akhlak learning needs an innovation in learning process in order to form a faith based on the understanding and knowledge of students. This study aims to describe the brain based learning method in akidah akhlak moral learning. The method of this study used a descriptive approach with literature review. This article explains that there are various ways that can be used in aqidah akhlak learning using the brainbased learning method including: 1) aqidah akhlak learning can be carried out by memorizing methods, 2) learning by showing pictures, 3) visualization in the form of videos and etc, so that with the brain based learning method the students could be more active and enthusiastic in aqidah akhlak learning process. In addition, using this method is good to increase students' knowledge generally.

Keywords:Learning, Akidah Akhlak, Brain Based Learning.

This work is licensed under a Creative Commons Attribution-ShareAlike 4.0 International License. Allows readers to read, download, copy, distribute, print, search, or link to the full texts of its articles and allow readers to use them for any other lawful purpose.

Copyright (c) 2020 Safinatur Robikah

Received 12 Januari 2021, Accepted 17 Mei 2021, Published 04 Juni 2021 


\section{A. Pendahuluan}

Pendidikan merupakan suatu proses yang mana dilaksanakan secara sadar serta tersusun guna menjadikan lingkungan belajar serta pembelajaran untuk siswa supaya siswa dapat mengasa kemampuan yang dimiliki untuk memperoleh kekuatan spiritual keagamaan, ataupun pengendalian diri, memiliki kepribadian, kemampuan, akhlakul karimah, sekaligus terampil yang bermanfaat untuk bangsa, Negara sekaligus individu itu sendiri. Dalam arti lain pendidikan ialah sebuah usaha yang dilakukan untuk mewujudkan siswa yang memiliki rasa kasih sayang, cinta tanah air sekaligus bertaqwa kepada Allah sebagai bentuk rasa syukur pada sang pencipta (Tatang, 2012).

Pembelajaran akidah akhlak ialah suatu pembelajaran yang dilaksanakan agar memperoleh keperayaan pada Allah SWT sekaligus meningkatkan akhlak yang mulia yang berpegang terhadap Al-Qur'an sekaligus As-Sunnah berdasarkan dengan apa yang telah dipelajari. Akidah akhlak termasuk salah satu dari materi pendidikn agama Islam. Dimana dalam materi tersebut dijelaskan terkait dasardasar keimanan terhadap Allah sekaligus nilai-nilai tauhid lainnya. Kemudian juga mengkaji tentang konsep akhlak sekaligus nilai-nilai yang terkandung di dalamnya. Pembahasan akidah akhlak tersebut menjadi penting supaya siswa mempunyai pengetahuan serta pemahaman yang utuh tentang keimanan, dan nantinya akan mewujudkan nilai-nilai keimanan dalam kehidupan yang nyata di masyarakat dalam bentuk akhlak yang baik. Maka dari itu, hal inilah yang menjadi salah satu urgensi pendidikan akidah akhlak, yang tujuannya adalah untuk memadukan antara konsep dan implementasi hablumminallah dan hablumminannas dengan baik dan seimbang (Rofiah, 2016).

Secara spiritual pendidikan aqidah akhlak dapat mendukung manusia menjadi sosok dengan akhlak yang baik sekaligus berbudi pekerti yang luhur pada sesamanya. Terlebih lagi, dengan menanamkan akhlak pada manusia akan membuat individu tersebut lebih menghargai terhadap ciptaan Allah baik makhluk tumbuhan atau individu manusia dan semua yang ada di dunia ini, selain itu paling utama adalah bertakwa kepada Allah SWT. Dimana aqidah akhlak sendiri termasuk sendi dari kehidupan umat muslim yang sangatlah penting. Aqidah akhlak juga merupakan penentu arah tujuan hidup manusia. Jika aqidah akhlaknya baik maka kehidupannya secara lahir dan batin akan terasa damai, namun sebaliknya jika aqidah akhlaknya buruk maka rusaklah kehidupannya. Oleh karenanya, aqidah akhlak merupakan salah satu kunci jatuh bangunnya peradaban suatu bangsa. Aqidah ahlak merupakan sebuah kepercayaan yang bersih sekaligus kebimbangan dan keraguan dimana hati membenarkannya sehingga timbullah ketenangan jiwa (Nursiyam, 2015).

Pada dunia pendidikan masih terdapat adanya anggapan bahwa siswa yang memiliki prestasi dan nilai yang gemilang merupakan siswa yang baik tanpa memedulikan akhlaknya. Oleh karenanya, pendidikan dikembangkan secara terus menerus agar kegiatan belajar mengajar dapat membantu siswa mencapai tujuan 
pendidikan (Azzet, 2011). Berdasarkan hal tersebut pendidikan akidah akhlak menjadi penting untuk dikemas semenarik mungkin supaya siswa tidak hanya memiliki prestasi yang gemilang saja tetapi juga dibarengi dengan iman dan akhlak yang gemilang. Eric Jansen menjelaskan bahwa brain based learning termasuk pelaksanaan pembelajaran mengaplikasikan kemampuan otak dimana ketika pembelajaran tersebut berlangsung dirancang dan disesuaikan berdasarkan cara siswa bekerja secara alamiah. Singkatnya dapat dipahami yakni brain based learning merupakan pembelajaran yang diselaraskan dengan cara otak dirancang untuk belajar (Jensen, 2011).

Belajar mengajar dengan berbasis kemampuan otak merupakan cara berpikir tentang sebuah kegiatan belajar mengajar yang dilaksanakan. Dalam diri seseorang terdapat dua jenis otak yakni otak kanan dan juga otak kiri manakala keduanya tersebut difungsikan secara bersamaan maka kekuatan serta fungsi dari keduanya tersebut akan bekerja secara optimal. Ketika kedua otak tersebut digunakan dampak positif yang bisa dirasakan ialah akan lebih meningkatnya kecerdasan individu tersebut. Hal ini, disebabkan karena jika antara otak kiri jika digunakan secara seimbang akan membuat seseorang mudah untuk menemukan kata-kata yang tepat guna mengungkapkan diri maupun perasaan. Mudah meningkat dan belajar hal-hal baru serta merenungkan kembali perkataan dan perbuatan yang telah terjadi. Maka dari itu akan membuat siswa semakin cerdas dan produktif (Wijanarko \& Setiawati, 2017). Oleh karena itu, penggunaan metode brain based learning dalam mengembangkan kemampuan berpikir siswa pada pembelajaran akidah akhlak penting untuk dibahas.

\section{B. Hasil Dan Pembahasan}

\section{Model Braind Based Learning}

Brain based learning didefinisikan dalam tiga kata yakni: keterlibatan, strategi, dan prinsip. Brain based learning adalah keterlibatan strategi yang didasarkan pada prinsip-prinsip yang berasal dari satu pemahaman tentang otak (Pratiwi \& Nugrahanta, 2020). Tiap-tiap orang mempunyai potensi otak yang sama luar biasanya, hanya saja tiap orang memiliki kemampuan yang berbeda disebabkan bagaimana cara mereka mengoptimalkan kemampuan otak tersebut. Brain based learning merupakan suatu konsep untuk menciptakan pembelajaran dengan mengoptimalkan pemberdayaan otak siswa. Brain based learning berasal dari teori neuroscience. Sebagaimana yang diungkapkan oleh Lopez \& Alipoon (2001) bahwa apa yang diperoleh dari neuroscience itu harus diintegrasikan dengan bidang pendidikan, psikologis dan bukti empiris dari pengalaman yang ada sebelum merancang strategi pembelajaran. Sehingga pada akhirnya perkembangan teori neuroscience dapat digunakan dalam pembelajaran di kelas (Rulyansah, Hasanah, \& Wardana, 2017).

Dimana sebuah pengalaman termasuk dari bagian terpenting pada teori otak. Sebagaimana didasarkan pada riset pendidikan sekaligus teori otak 
(neuroscientific) National Research Counsil Amerika Serikat (dalam Ronis, 2011:xviii) yang menunjukkan hasil temuan mereka pada baru-baru ini yakni: 1) system kerja fungsi otak sekaligus pekiran didasarkan pada pengalaman sekaligus mendapatkan manfaat yang posistif berdasarkan pengalaman tersebut, 2) perkembangan bukan sekedar proses tertutup yang dikembangkan secara biologis, melainkan juga proses aktif yang memberikan informasi terpenting dalam pengalaman yang diperoleh, dan 3) dampak yang dihasilakan oleh pengalaman itu sangat kuat dalam periode yang snsitif, sedangkan pengalaman yang lain mampu mempengaruhi otaks elama kurun waktu yang lama (Rulyansah dkk., 2017).

Jensen menjelaskan bahwa Brain based learning ialah model pembelajaran menyeimbangkan otak manusia dalam bekerja, sekaligus pertimbangan kinerja otak saat mengambil, mengelolah sekaligus mencerna informasi yang telah ditangkap ketika belajar mengajar berlangsung. Strategi utama yang dapat dikembangkan dalam pembelajaran brain based learning menurut Wisudawati \& Anggraini antara lain menciptakan lingkungan belajar yang menantang kemampuan berfikir siswa, menciptakan lingkungan pembelajaran yang menyenangkansehingga diharapkan siswadapat lebih memahami pembelajaran yang disampaikan dan menciptakan situasi pembelajaran yang aktifdan bermakna bagi siswa. Dimana kegiatan pembelajaran yang dilaksanakan dengan penuh pengalaman dilandaskan pada cara kerja dan struktur otak mampu meningkatkan kecerdasan bagi siswa (Pratiwi \& Nugrahanta, 2020).

Adapun penerapan pembelajaran menggunakan metode brain based learning terdiri dari beberapa tahapan diantaranya:

a. Tahap awal penyampaian, dalam tahap ini merupakan langkah pertama dalam proses pembelajaran dimana pendidik memberikan sebuah gambaran/ringkasan materi yang akan disampaikan secara umum mengaplikasikan bantuan media maind maping (peta konsep).

b. Tahap persiapan, dimana pendidik mempersiapkan sebuah pembelajaran, keadaan didalam kelas supaya siswa tertarik mengikuti pembelajaran dikelas. Pada tahapan ini pendidik juga mencoba mengkaitkan materi pembelajaran yang akan disampaikan sesuai dengan kondisi kehidupan sehari-hari siswa.

c. Tahap inisiasi serta akuisisi, dalam tahapan ini pendidik diharuskan memberikan rincian penjelasan materi terhadap siswa serta mengajarinya agar memahami sekaligus mampu menggali kembali informasi tentang materi yang telah dipelajari.

d. Keempat tahap elaborasi, merupakan tahap pemrosesan dimana dalam tahapan ini siswa secara leluasa untuk mencari, menyaring, mengamati serta memperdalam materi pelajaran yang telah dipelajari. Sehingga dalam tahapan pembelajaran tersebut memberikan kesan sebuah pembelajaran yang intelektual.

e. Tahap inkubasi sekaligus memasukan memori, merupakan tahapan dalam memberikan waktu beristirahat bagi siswa sekaligus waktu untuk mengulas kembali materi yang telah diperoleh. Hal tersebut dilakukan karena dalam 
proses kerja otak itu dilakukan secara bertahap bukan secara terus menerus dimana adakalanya otak butuh istirahat sejenak agar mampu menyerap informasi yang telah diterima dengan baik.

f. Tahap verifikasi serta pengecekan keyakinan, pada tahapan ini tugas pendidik ialah memeriksa kembali apakah materi yang disampaikan tadi dapat dimengerti dan dipahami oleh siswa begitu juga sebaliknya. Dalam tahapan ini pendidik dapat memastikan dengan cara mengulas sekaligus mengevaluasi materi yang telah di sampaikan kepada siswa.

g. Tahap perayaan serta integrasi. Keterlibatan emosi dalam tahap ini sangatlah penting. Dalam tahapan ini pendidik mememberikan sebuah reweard terhadap hasil pembelajaran yang dilaksanakan oleh siswa, dan hal tersebut dirasa akan berkesan sekaligus dapat memacu semangat belajar bagi siswa. Selain itu dalam penutup pembelajaran diberikan kesan yang menyenangkan seperti halnya diberikan penghargaan atau perayaan kecil.

Sementara itu, Caine menyampaikan bawa ada beberapa prinsip prinsip pembelajaran yang dilakukan dengan menggunakan metode brain based learning diantaranya yakni: (1) Memori manusia dibagi menjadi dua yaitu memori spaisal serta hafalan, (2) Learning engages the entire physiology (belajar dengan terlibatnya semua anggota organ manusia). (3) Every brain simultaneously perceives and creates parts and wholes (Setiap otak memproses keseluruhan dan bagian-bagian secara serentak).

Berdasarkan prinsip model pembelajaran brain based learning di atas dapat disimpulkan bahwa tiap individu memiliki otak yang berpotensi agar selalu berkembang, maka dari itu, bagi pendidik perlu melakukan pertimbangan terkait hal tersebut. Otak yang ada pada diri individu termasuk jenis organ individu paling kecil serta berperan penting terhadap tubuh manusia. Seluruh anggota tubuh manusia dapat beraktivitas karena digerakkan oleh otak terutama untuk belajar.

\section{Hubungan Antara Brain Based Learning Dengan Otak Siswa}

Metode brain based lerning ketika dalam pembelajaran memberikan sebuah konsep belajar yang berorientasi dengan langkah pemberdayaan otak siswa (Widana, Wira Bayu, \& Laba, 2010). Berdasarkan konsep tersebut dapat diartikan bahwa kemampuan otak siswa dalam memperoleh pengetahuan bukanhanya didapat dari pendidik saja, tetapi juga berasal dari pola pikir siswa itu sendiri. Pembelajaran dengan metode brain based learning melibatkan tiga kemampuan dari otak yakni: otak rasional (IQ), otak emosional (EQ), dan otak spiritual (SQ). Ketiga otak tersebut dapat dijelaskan sebagai berikut:

a. Otak rasional memiliki warnaabu-abu yang terdapat pada otak besar di bagianpusat (Suyadi, 2017). Cara kerja otak tersebut mengacu terhadap kemampuan akal pikiran dalam belajar maupun mengatasi suatu permasalahan dengan baik sesuai dengan akal pikiran mereka. Dalam pembelajaran akidah akhlak yang notabenenya adalah mewujudkan manusia yang beriman serta 
mengesakan Allah dalam setiap perbuatannya juga memiliki akhlak yang baik terhadap sesama dan juga makhluk lain yang ada disekitarnya memerlukan peranan dari otak rasional. Dimana hal ini berdasarkan pada sifat individu yang condong melakukan untuk berbuat baik dan meninggalkan perbuatan yang tidak baik.

IQ akan berfungsi manakala disertai dengan otak emosional dan juga otak spiritual. Oleh karena itu, sudah jelas bahwa pendekatan otak secara keseluruhan menunjukkan bahwa masalah kognisi dan emosi merupakan suatu kesatuan yang tidak mungkin dapat dipisahkan. Begitu halnya berlaku dalam proses pembelajaran dimana ketika pembelajaran akal pikiran siswa perlu melibatkan emosional hal tersebut dapat dilakukan dengan mengemas sebuah pembelajaran dengan sebaik-baiknya, seperti halnya dilakukan dalam bentuk gambar, suara maupun bacaan/ceramah. Namun langkah utama bagi pendidik untuk dapat memasuki dimensi emosi-spiritual siswa ketika pembelajaran dapat di awali dengan berdoa (Suyadi, 2017).

Otak siswa dapat bekerja secara keseluruhan dalam pembelajaran baik itu pembelajaran yang dilakukan di dalam ruangan maupun di luar ruangan, mana kala pembelajaran tersebut banyak dilakukan dengan memberikan stimulus. Nah dalam memberikan stimulus untuk membangun motivasi pada diri siswa diperlukan pemahaman akan emosi siswa secara menyeluruh oleh pendidik. Ketika pembelajaran dilakukan hanya dengan metode ceramah tanpa melakukan hal lain yang berkesan, maka nantinya hasil tersebut akan ditangkap oleh otak siswa yang bagian kiri yang itu sifatnya sementara (memori jangka pendek), begitu pula dengan sebaliknya jika pembelajaran tersebut dikemas dengan hal yang menarik seperti halnya disampaikan dengan bentuk gambar dengan berbagai bentuk dan warna sesuai dengan isi materi maka informasi materi tersebut dapat melekat pada memori siswa dalam jangka waktu yang lama. Oleh karenanya, ketika penyampaian pembelajaran pada siswa saat proes pembelajparan seharusnyae tidak disajikan berdasarkan bacaan saja tetapi dapat disampaikan dalam bentuk yang menarik seperti halnya gambar, video dan lain sebagainya supaya informasi yang disampaikan oleh pendidik tersebut dapat dicerna oleh memori jangka panjang.

b. Otak yang berpusat pada limbik disebut juga dengan otak emosional (EQ) (Suyadi, 2017). Mengenai namanya, otak emosional adalah otak individu yang berkembang berdasarkan emosi. Dimana perkembangan, pemikiran, partisapan siswa lebih dulu mendominasi pemikiran emosional dari pada pemikiranrasional. Perlu diperhatikan bahwasanya otak emosional juga dapat memberikan rasa senang, bersemangat, dan cekatan tidak hanya hal-hal yang berhubungan dengan emosi saja atau sesuatu sifatnya menjengkelkan (Suyadi, 2017). Otak rasioanal memerlukan peran dari otak spiritual agar dapat bekerja karena otak rasional tidak dapat bekerja sendiri. Dalam diri manusia yang disampaikan oleh Damasio bahwa perilaku irrasional (perilaku yang bertolak 
belakang dengan akal)yakni sumber utama dari emosi manusia yang tidak terkontrol atau tidak terarah, tetapi dengan mengurangi emosi dapat mencegah terjadinya prilkaku melainkan dalam irrasional pada diri manusia. Dimana kecerdasan emosional termasuk hasil dari pembentukan emosional siswa.

Pengaplikasian otak emosional individu perlu diimbangi dengan mengendalikan emosi seseorang, dikarenakan ketika emosi seseorang meluap secara berlebihan juga tidak dapat terkendali dengan baik sekaligus terarah maka akan tersalurkam sebuah energi negatif yang akan mempengaruhi emosi seseorang, begitu juga sebaliknya jika emosi tersebut mampu untuk dikendalikan dengan baik maka emosional manusia tersebut akan terbentuk menjadi positif.

c. Otak manusia yang berada pada lobus tempora yang merupakan pusat tentang pengetahuan disebut dengan otak spiritual (SQ). Dalam hal ini otak tersebut membangkitkan kesadaran neurologi spiritual yang tinggi. Hal tersebut berdasarkan adanya sel-sel yang berwarna kelabu yang ada pada otak manusia, hasil kinerja dari sel-sel kelabu yang berada dalam otak manusia tersebut merupakan titik permulaan munculnya sebuah pemikiran yang nyata menuju tingkat kesadaran yang tinggi (spiritualitas). Secara umum fungsi dari susunan otak spiritual dan norma merupakan suatu pelembagaan nilai yang ada pada diri manusia itu sendiri. Bentuk perwuju dan dari fungsi otak spiritual yakni ketika seseorang menganut sebuah keyakinan yang dianggap benar menurut dirinya.

Otak spiritual, disebut dengan tempat terjadinya kontak antar makhluk terhadap penciptanya melalui alam pikiran keadaan tersebut memiliki peran jika secara optimal IQ serta alat indera sudah digunakan. Siswa yang menerima petunjuk dari Allah akan dengan mudah memahami pembelajaran jika mereka menggunakan kemampuan otak secara menyeluruh. Otak internal manusia berfungsi untuk kesadaran diri seseorang. Kesadaran tersebut akan tetap ada walaupun tanpa didasarkan rangsangan dari luar diri individu itu sendiri.

Cara kerja dari otak spiritual yakni bekerja secara intuitif yang menghasilkan kemampuan spiritual. Otak spiritual (SQ) pada dasarnya ialah intelegensi berguna dalam mengatasi serta menyelesaikan permasalahan, terlebih terkait nilai sekaligus arti kehidupan. Otak spiritual (SQ) yang kuat akan dijadikan pijakan kuat guna menfungsikan otak rasional (IQ) serta otak emosional (EQ) secara efektif. Otak spiritual (SQ) berfungsi sebagai pembanding antara baik dan buruk.

Secara keseluruhan, meneliti masalah tersebut baik terlihat atau tidak terlihat, dan memikirkannya secara mendalam adalah salah satu bentuk optimalisasi dari otak spiritual. Ketika berdoa dapat dilakukan dengan berbagai cara sesuai dengan kepercayaan agamanya. Dan doa merupakan cara yang digunakan untuk mengoptimalkan otak manusia. Dimana langkah tersebut akan mendukung pemecahan masalah menggunakan otak emosional, intuitif, dan keagamaan (Suyadi, 2017). 


\section{Pembelajaran Akidah Akhlak Menggunakan Brain Based Learning}

Brain based learning termasuk sebuah konsep dalam menciptakan pembelajaran denagan berorientasi terhadap pemberdayaan kemampuan otak siswa (Chamidiyah, 2015). Otak manusia memiliki peran yang besar dalam pengembangan belajar mengaplikasikan metode brain based learning. Sesuai dengan kemajuan pendidikan di zaman sekarang, dimana interaksi pembelajaran tidak dapat terarah jika seorang pendidik dalam melaksanakan pembelajaran hanya menggunakan teknik pembelajaran seperti biasa dan siswa hanya mendengarkan saja. Ali ibn Abi Thalib pernah berkata, "janganlah engkau didik anakmu sebagaimana engkau dulu mendapatkan pendidikan karena mereka dilahirkan di zaman yang berbeda dengan zamanmu" (Suyadi, 2017).

Pada zaman dahulu pembelajaran hanya disampaikan lewat lisan atau bisa dikenal dengan ceramah. Namun dalam pembelajaran dimasa sekarang banyak sekali cara yang dapat dilakukan dalam penyampaian materi tersebut. Sebagaimana jika pembelajaran materi aqidah akhlak dapat disampaikan dengan bentuk penulisan opini maka secara otomatis siwa sudah melakukan pembelajaran dengan berbagai cara yakni dari mulai membaca, memahami materi, sekaligus menyimpulkan materi-materi yang ada. Dengan melalui penulisan opini juga dapat membantu siswa dalam mengingat meteri pelajaran (Dedi, 2017). Dimana secara substansional pembelajaran aqidah akhlak berkontribusi untuk member motivasi kepada siswa untuk mempelajari dan mempraktikkan akidahnya dalam bentuk pembiasaan untuk melaksanakan akhlak yang terpuji sekaligus menghindari akhlak tercela dalam kehidupan sehari-hari (Kutsiyyah, 2019).

Sebagian seorang pendidik konvensional harus menyadari akan perbedaan siswa di era saat ini dengan era sebelumnya, yang mana siswa di masa ini lebih condong memperoleh pengetahuan secara langsung, siswa masa ini juga condong melaksanakan suatu hal yang sifatnya intermeso atau bersifat menyenangkan dan tidak membosankan, keadaan tersebut disebabkan oleh pesatnya ilmu pengetahuan sehingga siswa dengan mudah untuk memperoleh informasi baik itu sifatnya bermanfaat ataupun merugikan. Oleh karenanya, diperlukan pembaharuan pendidikan, terkhusus pada pembelajaran aqidah akhlak supaya siswa dapat memperkuat sendi keislamannya.

Pendidikan karakter yang saat ini diagung-agungkan oleh Kemendiknas sebagaimana yang dikatakan oleh Suyadi merupakan kata lain dari Budi Pekerti menurut pemikiran Ki Hajar Dewantara (Ibrahim, 2019), sedangkan Ahmad Amin mengatakan bahwa permulaan terjadinya karakter seseorang merupakan keinginan atau niatan yang terdapat dalam diri orang tersebut yang kemudian diimplementasikan melalui tindakan serta perbuatan orang tersebut. Dalam pembelajaran aqidah akhlak metode brain based learning dijadikan sebuah tempat supaya dapat mengembangkan karakter insan mulia sesuai dengan sains siswa serta di dukung dengan daya intelektual siswa yang tinggi dari brain based learning tersebut. 


\section{Penerapan Pembelajaran Akidah Akhlak Dengan Metode Brain Based Learning}

Jensen (2011) dalam Laksmi (2014) menjelaskanmetode brain based learning memiliki tiga strategi utama yakni mewujudkankemempuan berpikir bagi siswa yang berasal dari lingkungan belajar siswa, terbentuknya proses pembelajaran yang menyenangkan, serta menjadikan siswa yang lebih aktif dalam pembelajaran. Berdasarkan hal tersebut model pembelajaran brain based learning dapat menimbulkan keaktifan dalam proses belajar mengajar bagi siswa (Ibrahim, 2019).

Terdapat berbagai cara sederhana yang dapat dilakukan di kelas maupun dirumah, yakni sebagai berikut: 1) menggabungkan keseluruhan bagian otak siswa dengan mengaktifkan VAKOG (Visual-Auditori-Kinestetik-Olfaktori-Gustatori). 2) mengasosiasikan pelajaran yang diberikan dengan kehidupan nyata bagi siswa atau dengan sesuatu yang dikenali bahkan disenangi. 3) menciptakan asosiasi informasi. 4) menggunakan warna dalam pembelajaran. 5) pembelajaran dengan menggunakan musik (Santioso \& Rizky, 2012). Dari berbagai cara tersebut dapat diaplikasikan dalam pembelajaran.

Adapun strategi yang dapat digunakan dalam menerapkan metode brain based learning pada pembelajaran akidah akhlak diantaranya:

a. Kreatifitas seorang pendidik sangatlah penting dalam melakukan proses pembelajaran. Dimana dalam pelaksanan pembelajarannya seorang pendidik bukan hanya menggunakan metode ceramah saja dalam penyampaiannya melainkan juga dituntut untuk lebih kreatif, hal ini bias dilakukan seperti halnya pada materi Rukun Iman dan Islam pendidik bias kreatif dalam menyampaikan meteri tersebut dengan memanfaatkan anggota tubuh siswa sebagai metode dalam menghafalnya. Contoh pengaplikasian anggota tubuh siswa dalam menghafal materi yakni pendidik dapat menggunakan salah satu jari tangan, missal untuk menghafal Rukun Iman yang pertama pendidik dapat mengangkat jari telunjuk ke atas sebagai tanda bahwa beriman Kepada Allah, begitu juga seterusnya yang mana setiap gerakan dalam menghafal tersebut gerakan tubuh yang dilakukan berbeda-beda.

b. Melalui media gambar. Pembelajaran dengan menggunakan media gambar ini lebih cocok untuk diaplikasikan pada siswa pada jenjang SD/MI. Contoh pengaplikasian pembelajarannya yakni pendidik memeberikan sebuah petanyaan terkait tentang meteri Aqidah Akhlak kemudian siswa diminta untuk menjawab pertanyaan tersebut tetapi jawabannya ditulis dalam bentuk gambar bukan uraian tulisan. Dengan menggunakan metode menggambar ini siswa akan lebih semangat dan termotivasi untuk lebih giat dalam belajar dan fokus pada materi yang di sampaikan sekaligus dapat mempertajam daya ingat siswa.

c. Pembelajaran akidah akhlak dengan gambar visualisasi. Belajar menggunakan visualisasi gambar ini hampir sama seperti pembelajaran yang mengaplikasikan 
metode proses menggambar, tetapi metode ini penerapannya kebalikan dari metode tersebut. Dalam menggunakan metode ini memakai gambar sebagai bentuk pembelajaran dalam aqidah akhlak. Contoh penerapannya: siswa disajikan sebuah gambar orang sedang makan dengan berdiri, setelah mengamati gambar tersebut guru meminta siswa untuk mengidentifikasi perilaku atau akhlak siswa tersebut sesuai dengan gambar apakah perilaku tersebut termasuk perbuatan yang baik atau tidak, maka dari gambar tersebut anak bisa memyebutkan bahwa perilaku tersebut tidak baik dan tidak perlu untuk di contoh. Setelah mengetahui perilaku tersebut tidak mencerminkan akhlak yang baik diharapkan siswa mampu menerapkan bagaimana akhlak yang baik yang seharusnya dilakukan sesuai dengan gambar yang diidentifikasi tadi. Metode tersebut memiliki tujuan supaya siswa mempunyai tingkat kepedulian terhadap lingkungan sekitar supaya dalam lingkungan bermain maupun lingkungan keluarga dapat tercipta kondisi yang baik dan nyaman serta diharapkan siswa mamapu memahami kondisi dirinya sendiri.

d. Media video dalam proses pembelajaran. Pengaplikasian proses pembelajaran tersebut yakni pendidik memutarkan sebuah video yang terkait dengan materi dalam penyampaian meteri pembelajaran baik itu tentang video yang berkaitan dengan sesuatu hal yang baik maupun buruk, nanti setelah video selesai dilihat pendidik meminta siswa untuk memahami dan menjelaskan kembali hal apa yang terkandung dalam video tersebut. Melalui pembelajaran seperti ini. Siswa akan lebih memahami materi yang diperkenalkan juga, memahami menggunakan video ini sangat menarik untuk mempersiapkan gaya penalaran siswa, dikarenakan siswa sangat siap untuk memahami dan memahami materi yang terdapat pada video.

e. Pembelajaran akidah akhlak dengan menggunakan media komunikasi dengan menggunakan media komunikasi ini dirasi lebih efektif dimana dalam pembelajaran di sekolah pendidik dijadikan sebagai teladan yang dijadikan panutan untuk siswa.

Dimana pendidik akan merasa terbantu dan dimudahkan jika dalam penyampaian pembelajarannya mengaplikasikan salah satu dari langkah-langkah pembelajaran tersebut, dan juga pembelajaran dengan menggunakan langkah tersebut akan menjadikan siswa untuk lebih berpikir kritis termasuk dalam hal akidah dan akhlak siswa yang sejalan dengan kehidupan sehari-hari. Pembelajaran dengan metode tersebut dalam pengaplikasiannya di mata pelajaran akidah akhlak akan menimbulkan perkembangan kognitif serta kemampuan mengeksplor olah pikir siswa.

\section{Kelebihan dan KekuranganPembelajaranAkidahakhlakMenggunakan Model Brain Based Learning}

Kelebihan pendidikan akidah akhlak dengan menggunakan metode brain based learning antara lain adalah: 
a. Pada proses belajar mengajarnya dapat menggunakan berbagai metode pembelajaran.

b. Otak manusia akan lebih baik jika dalam pembelajaran menggunakan berbagai model pembelajaran hal ini sama halnya denagan pembelajaran akidah akhlak dengan menggunakan model brain based learning.

c. Ketika menggunakan metode brain based learning akan menghasilkan kemampuan kerja secara alamiah otak siswa dalam mencerna pembelajaran.

d. Metode pembelajaran berbasis otak menggunakan ide-ide yang dapat dikembangkan di otak siswa untuk difokuskan pada kinerja siswa.

e. Menggunakan metode pembelajaran berbasis otak untuk mempelajari etika akan menjadi lebih modern dan baru.

f. Pembelajaran menggunakan metode pembelajaran berbasis otak tergolong pembelajaran baru karena masih sedikit lembaga yang menggunakan metode ini untuk pembelajaran.

g. Pembelajaran akidah akhalak yang menggunakan metode brain based learning akan menciptakan pembelajaran yang menyenangkan sesuai dengan cirri khas dari metode tersebut (Ibrahim, 2019).

Sedangkan kelemahan pendidikan akidah akhlak menggunakan metode brain based learning antara lain adalah;

a. Pendidik Indonesia belums epenuhnya memahami teori pengetahuan tentang pembelajaran berbasis otak.

b. Sosialisasi diperlukan agar pendidik memahami pembelajaran berbasis otak dan dapat mempraktikkannya kepada siswa.

c. Perlu waktu lama untuk memahami bagaimana otak bekerja dalam prosesnya.

d. Pemahaman ini akan lebih cepat jika terbiasa dengan suasana belajar dengan menggunakan pembelajaran berbasis otak

e. Perlu dana untuk menciptakan model pembelajaran yang baik untuk otak (Ibrahim, 2019).

\section{Simpulan}

Pembelajaran akidah akhlak dengan menggunakan metode brain based learning dapat dilaksanakan dengan berbagai cara diantaranya: (1) penyampaian materi akidah akhalak dengan teknik menghafal, (2) dengan teknik gambar, (3) visualisai yang berupa video maupun lainnya yang dapat ditepakan oleh pendidik dalam penyampaian materi akidah akhlak agar pembelajaran tersebut lebih aktif dan juga menumbuhkan semangat belajar pada diri siswa. Ada berbagai cara yang dapat dilakukan dalam pembelajaran di sekolah maupun di rumah yakni: 1) menggabungkan keseluruhan bagian otak siswa dengan mengaktifkan VAKOG (Visual-AuditoriKinestetik-Olfaktori-Gustatori). 2) mengasosiasikan pelajaran yang diberikan dengan kehidupan nyata bagi siswa atau dengan sesuatu yang dikenali bahkan disenangi. 3) menciptakan asosiasi informasi. 4) menggunakan warna dalam pembelajaran. 5) pembelajaran dengan menggunakan music Model pembelajaran dengan menggunakan 
metode brain based learning memiliki beberapa kelebihan antara lain: (1) menciptakan pembelajaran yang menarik serta dapat meningkatkan dan mengasah ilmu pengetahuan siswa, (2) metode ini dapat digunakan sebagai penentu potensi kemampuan yang dimiliki oleh siswa secara menyeluruh, (3) metode inidapatmemotivasisiswa untuk mengikuti pembelajaran dengan aktif dan semangat, (4) dapat membantu siswa mempunyai wawasan yang mendalam terkait materi yang disampaikan secara menyeluruh,serta menumbuhkan potensi siswa. Dengan menggunakan metode pembelajaran berbasis otak ini, siswa dapat lebih mengeksplorasi dirinya sendiri. Bisa berpikir kritis, mendalam, dan relevan. Permasalahan yang dihadapi, terutama tentang etika.

\section{Daftar Rujukan}

Azzet, A. M. (2011). Urgensi Pendidikan Karakter di Indonesia. Yogyakarta: Ar-Ruzz Media.

Chamidiyah, C. (2015). Pembelajaran Melalui Brain Based Learning dalam Pendidikan Anak Usia Dini. Edukasia: Jurnal Penelitian Pendidikan Islam, 10(2). https://doi.org/10.21043/edukasia.v10i2.795

Dedi, W. (2017). Pengantar Akidah Akhlak dan Pembelajarannya. Yogyakarta: Lintang Rasi Aksara Books.

Ibrahim, D. (2019). Pengaruh Model Pembelajaran Brain Based Learning Terhadap Aktivitas Belajar Siswa. Atthulab: Islamic Religion Teaching and Learning Journal, 1(2), 16-30. https://doi.org/10.15575/ath.v1i2.2525

Jensen, E. (2011). Pembelajaran Berbasis Otak: Paradigma Pengajaran Baru (2 ed.). Jakarta: Indeks.

Kutsiyyah, K. (2019). Pembelajaran Akidah Akhlak. Pamekasan: Duta Media Publishing.

Nursiyam, N. (2015). Pengaruh Sistem Pembelajaran Pesantren Kampus terhadap Penguatan Akidah dan Akhlak Mahasiswa IAIN Samarinda. SYAMIL: Jurnal Pendidikan Agama Islam (Journal of Islamic Education), 3(2). https://doi.org/10.21093/sy.v3i2.248

Pratiwi, A. R. W., \& Nugrahanta, G. A. (2020). Asyiknya Bermain Dengan Perminan Tradisional Untuk Mengasah Hati Nurani Anak. CV. Resitasi Pustaka. Diambil dari https://books.google.co.id/books?id=cqIqEAAAQBAJ

Rofiah, N. H. (2016). Desain Pengembangan Pembelajaran Akidah Akhlak Di Perguruan Tinggi. Fenomena Jurnal Penelitian, 8(1). Diambil dari https://journal.iain-samarinda.ac.id/index.php/fenomena/article/view/472

Rulyansah, A., Hasanah, U., \& Wardana, L. A. (2017). Model Pembelajaran Brain Based LearningBermuatan Multiple Intelegences. Banyuwangi: LPPM Institut Agama Islam Ibrahimy Genteng Banyuwangi.

Santioso, L. L., \& Rizky, A. J. (2012). Dahsyatnya Brain Smart Teaching: Cara Super Jitu Optimalkan Kecerdasan Otak dan Prestasi Belajar Anak / Lucy Lidiawati Santioso, Ade Julins Rizky. Jakarta: Penebar Plus. 
Suyadi, S. (2017). Teori Pembelajaran Anak Usia Dini dalam Neurosains. Bandung: PT. Rosda Karya.

Tatang, T. (2012). Ilmu Pendidikan. Bandung: Pustaka Setia.

Widana, W., Wira Bayu, G., Laba, N., \& Ayata. (2010). Pembelajaran Berbasis Otak (Brain Based Learning), Gaya Kognitif Kemampuan Berpikir Kreatif Dan Hasil Belajar Mahasiswa. Jurnal Pendidikan Indonesia, 3.

Wijanarko, J., \& Setiawati, E. (2017). Maksimalkan Otak Anak Anda Multiple Intelegences-Kecerdasan Majemuk Tips Menjadi Anak Cerdas. Jakarta: Keluarga Indonesia Bahagia. 